\title{
HISTORYCZNE MAPY GÓRNICZE ŹRÓDŁEM DANYCH GEOLOGICZNYCH - PRZYKLAD INTERPRETACJI STRUKTUR GLACITEKTONICZNYCH Z TERENU ZIELONEJ GÓRY
}

\author{
Agnieszka GONTASZEWSKA-PIEKARZ ${ }^{1}$ \\ Martyna SZCZEPANKOWSKA ${ }^{2}$ \\ ${ }^{1}$ Uniwersytet Zielonogórski, a.gontaszewska@ib.uz.zgora.pl \\ ${ }^{2}$ Absolwentka Uniwersytetu Zielonogórskiego, m.szczepankowska@o2.pl
}

\section{zaburzenia glacitektoniczne, podziemne górnictwo węgla brunatnego, mapy górnicze}

\begin{abstract}
Praca przedstawia analizę przedwojennych map górniczych, którą wykonano dla fragmentu terenu Zielonej Góry. Mapy te zawierają dane dotyczące położenia eksploatowanego pokładu węgla i oparte są na bezpośrednich pomiarach w pokładzie. Na ich podstawie wykreślono przekroje geologiczne, pokazujące przestrzenne położenie pokładu węgla brunatnego, a co za tym idzie, struktur glacitektonicznych. Typ oraz przebieg struktur uzyskanych z analiz map jest generalnie zgodny ze schematem budowy geologicznej, jaką zaprezentowano na Szczegółowej Mapie Geologicznej Polski (łuski i fałdy o biegu SW-NE), stwierdzono jednak dodatkowo glacitektoniczne zaburzenia drugorzędne.
\end{abstract}

\section{Wstęp}

Część lubuskich złóż węgla brunatnego związana jest ze strukturami zaburzonymi glacitektonicznie. W przypadku Zielonej Góry jest to morena utworzona podczas zlodowacenia Warty ze spiętrzonych warstw miocenu i starszego plejstocenu. Deformacje glacitektoniczne spowodowały sfałdowanie oraz złuskowanie pokładów węgla (Kupetz, 1997), co uczyniło je dogodnymi do eksploatacji. Warstwy węgla charakteryzują się nieciągłością oraz zmienną miąż- 
szością i upadem, do pionowego włącznie. Konsekwencją tych deformacji jest bardzo zmienna przestrzennie i trudna do interpretacji budowa geologiczna.

Kopalnie węgla brunatnego, które funkcjonowały w okolicy Zielonej Góry do 1946 roku są źródłem bardzo wielu danych na temat zalegania osadów mioceńskich $\mathrm{z}$ węglem brunatnym. Są to zarówno profile wierceń, jak i mapy eksploatowanych pokładów (ryc. 1).

Na mapach górniczych (z reguły w skali 1:1000) zaznaczono m.in. przebieg chodników transportowych, zasięg wyrobisk oraz upad pokładu węgla. Pozwala to na dość dokładne odtworzenie przebiegu struktur glacitektonicznych, gdyż warstwa węgla jest ich najbardziej czytelną częścią.

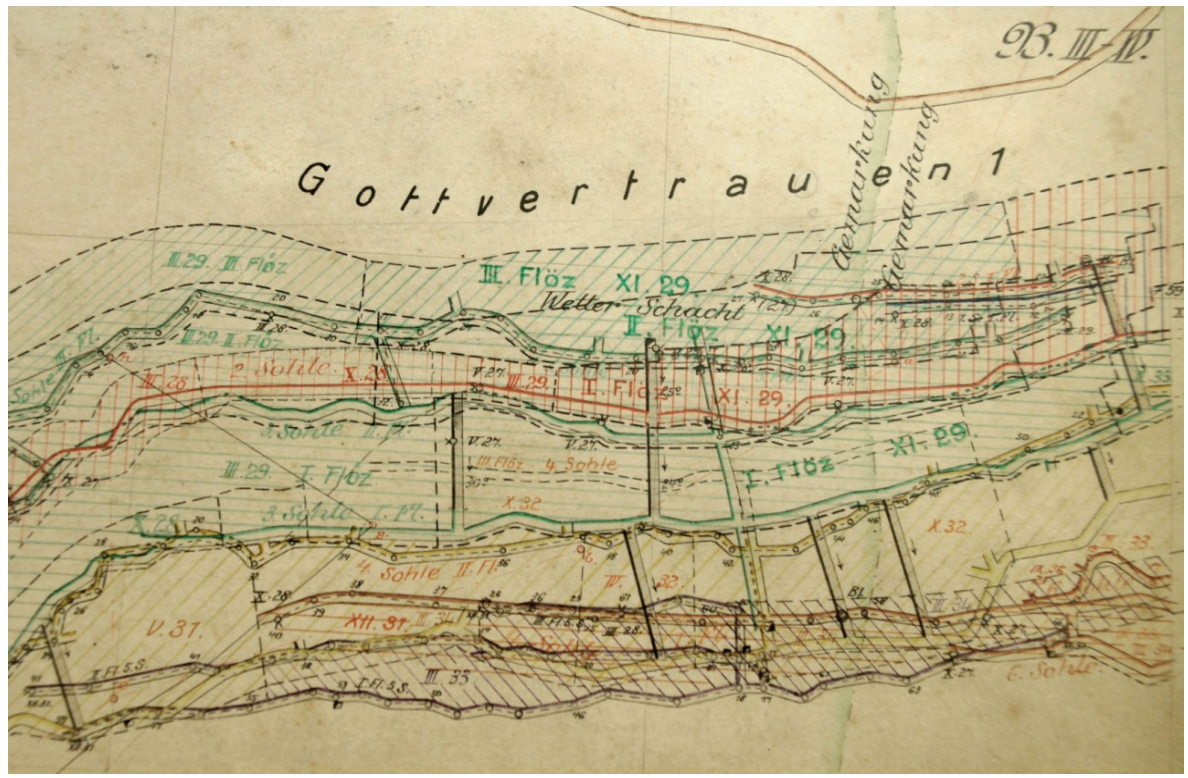

Ryc. 1. Przykład przedwojennej mapy górniczej w skali 1:1000, fragment mapy robót górniczych z roku 1943, kopalnia „Oskar” (Mapy robót..., sygn. 2099/1317)

Fig. 1. Example of prewar mine map (scale 1:1000), fragment of mine map from "Oscar" mine, 1943 (Mapy robót..., sygn. 2099/1317)

\section{Górnictwo węgla brunatnego w Zielonej Górze}

Węgiel brunatny w okolicy Zielonej Góry odkryto w roku 1838 na terenie wsi Wilkanowo, na zachód od miasta. Dnia 24 listopada 1840 powstał zakład górniczy o nazwie Friedrich Wilhelm, który w późniejszych latach stał się częścią gwa- 
rectwa Consolidierte Grünberger Gruben. Wydobycie rozpoczęto w październiku 1841 r. z szybu Emilie (Gontaszewska-Piekarz, 2018). Wydobycie węgla, aż do II wojny światowej wynosiło około $1 \mathrm{mln}$ hektolitrów (100 000 ton) rocznie. Węgiel miał zastosowanie przede wszystkim jako opał w silnikach parowych zielonogórskich fabryk i przędzalni. Po zakończeniu II wojny światowej wydobycie wznowiono, jednak w roku 1948 kopalnia uległa likwidacji. Wydobycie węgla brunatnego przez Consolidierte Grünberger Gruben rozpoczęło się na terenie dzisiejszej Zielonej Góry, a następnie było ono systematycznie przesuwane na zachód, w stronę wsi Wilkanowo oraz Słone. W latach 20. XX wieku eksploatacja koncentrowała się na zachodnich i południowo-zachodnich przedmieściach, a w latach 30 . XX wieku wydobycie odbywało się już głównie poza Zieloną Górą. Oprócz przedsiębiorstwa Consolidierte Grünberger Gruben w okolicy funkcjonowało (głównie w XIX w.) kilkanaście mniejszych kopalni.

Większość złóż węgla brunatnego eksploatowanych przed wojną na obecnej Ziemi Lubuskiej występowała w strukturach zaburzonych glacitektonicznie. W przypadku Zielonej Góry złoża węgla brunatnego występują w obrębie, utworzonej podczas zlodowacenia Warty, moreny zwanej Wałem Zielonogórskim. Glacitektonika miała ogromne znaczenie dla udostępnienia złóż. Przedwojenne wydobycie odbywało się prawie wyłącznie w strukturach zaburzonych w ten sposób - łuskach glacitektonicznych oraz antyklinach, zwanych w górnictwie siodłami węglowymi. Bieg tych struktur to SW-NE (ryc. 2, 3). Eksploatacji podlegały przegubowe części antyklin oraz ich skrzydła, do maksymalnej głębokości około $70 \mathrm{~m}$. Wydobycie prowadzono wyłącznie systemem podziemnym, metodą zabierkową na zawał, zwaną także filarowo-komorową.

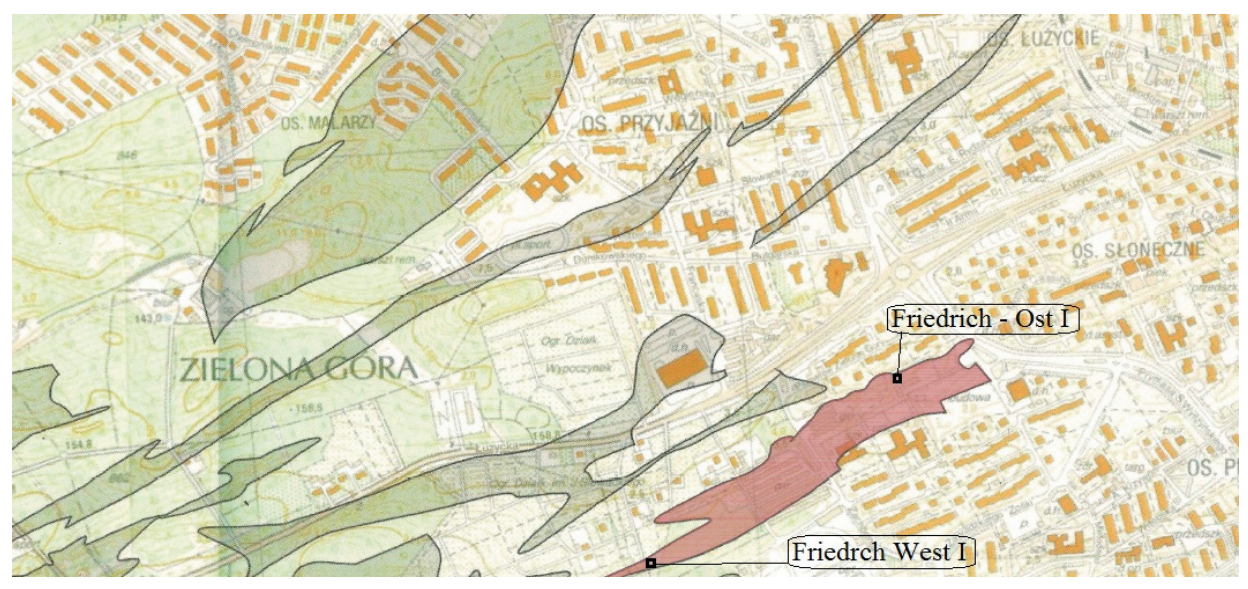

Ryc. 2. Pokłady węgla brunatnego w zachodniej części Zielonej Góry; zaznaczono omawiany w pracy pokład węgla

Fig. 2. Lignite bed of West part of Zielona Góra, described bed was marked 
Przedmiotem eksploatacji górniczej był I środkowopolski pokład węgla, zwany w Polsce Zachodniej pokładem Henryk, a w przedwojennej literaturze niemieckiej - Oberflöz. W nadkładzie pokładu występują najczęściej iły formacji poznańskiej. Miąższość pokładów zielonogórskiego węgla wynosi najczęściej zaledwie około 3-4 m.

\section{Budowa geologiczna okolic ulicy Godlewskiego w Zielonej Górze}

Dla fragmentu miasta (okolice ulicy Godlewskiego, południowo-zachodnia część Zielonej Góry - ryc. 2) wykonano analizę dostępnych map górniczych w skali 1:1000, porównując uzyskane wyniki z danymi dostępnymi z wierceń geologiczno-inżynierskich oraz ogólnym modelem budowy geologicznej, zaprezentowanym na Szczegółowej Mapie Geologicznej Polski (Szczepankowska, 2017).

Na podstawie map górniczych, zawierających pomiary wykonywane bezpośrednio w pokładzie węgla (m.in. kąt upadu), wykreślono uproszczone przekroje geologiczne, pokazujące jego zaleganie. Pokład ten eksploatowany był szybem Friedrich Ost I (ryc. 3, 4) na początku XX wieku.

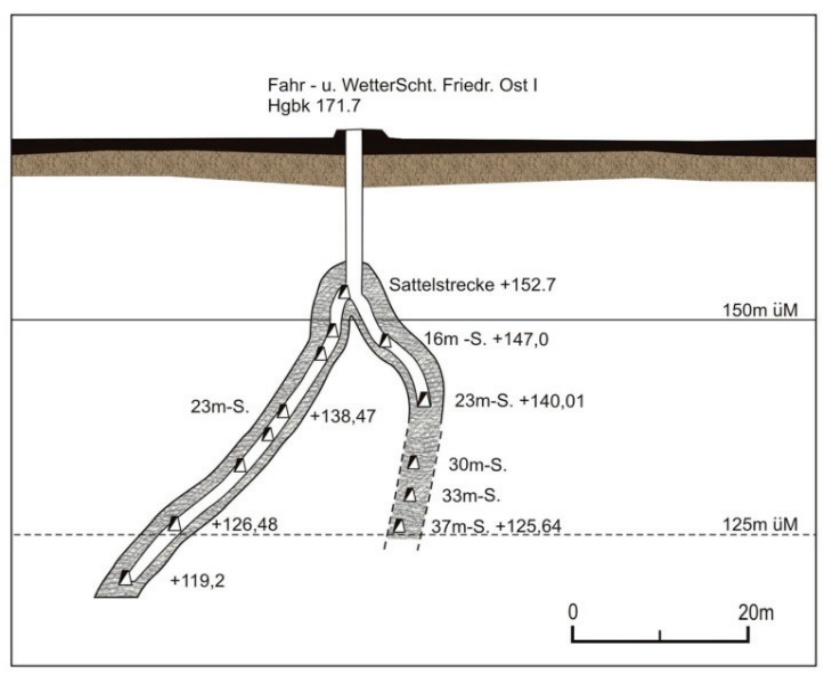

Ryc. 3. Schematyczny przekrój przez siodło węgla brunatnego udostępnione szybem Friedrich Ost I w Zielonej Górze (Gontaszewska \& Kłosiński, 2017); objaśnienia: $23 \mathrm{~m}-\mathrm{S}$ - chodnik na głębokości $23 \mathrm{~m}$, üM - n.p.m. Hgbk - rzędna nadszybia

Fig. 3. Simplified geological cross-section of saddle exploited by Friedrich Ost I shaft in Zielona Góra mine (Gontaszewska \& Kłosiński, 2017); explanations:

$23 \mathrm{~m}-\mathrm{S}$ - lignite bed at a depth of $23 \mathrm{~m}$, üM - above sea level; Hgbk - bank ordinate 


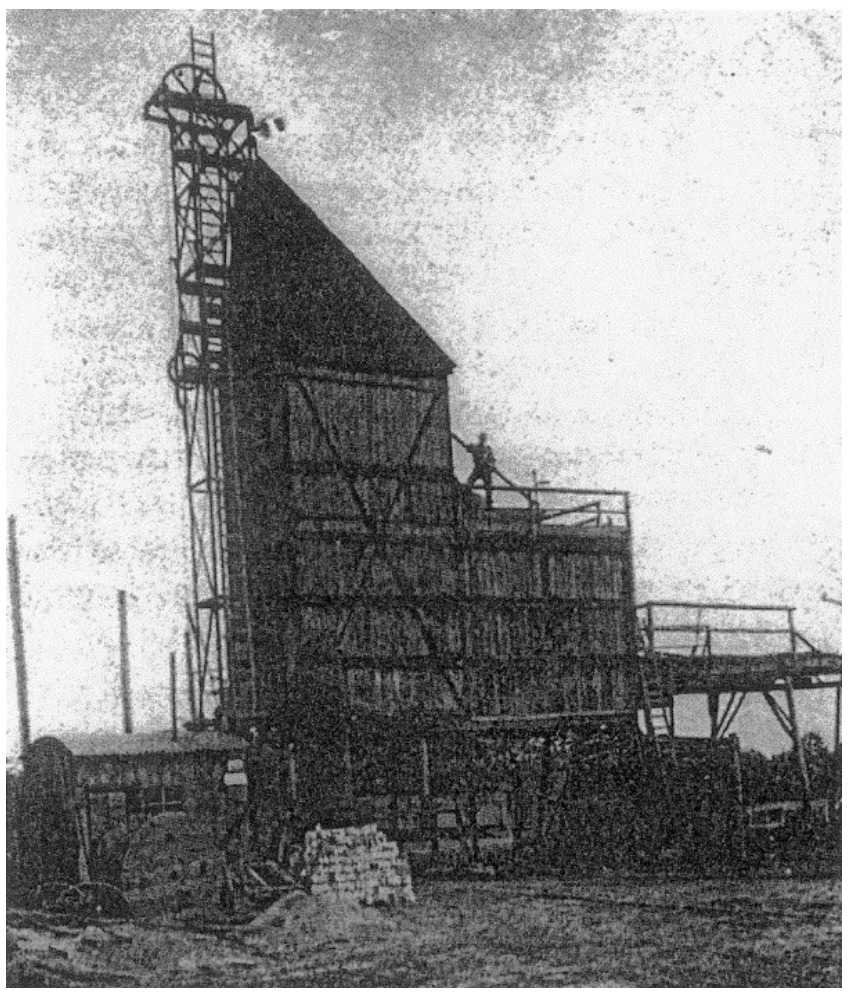

Ryc. 4. Szyb Friedrich Ost I (Kuleba, 2006)

Fig. 4. Friedrich Ost I shaft (Kuleba, 2006)

Dla tego samego terenu zostało przeprowadzone kilka lat wcześniej (m.in. przez jedną z autorek) rozpoznanie budowy geologicznej w związku z projektowanym posadowieniem budynków 7-kondygnacyjnych. Model budowy geologicznej uzyskany w trakcie badań geologiczno-inżynierskich pokazano na przykładowym przekroju (ryc. 5). Żadne z wykonanych wierceń (sięgały one do $25 \mathrm{~m}$ ) nie wykazało zalegania pokładu węgla brunatnego. Natrafiono natomiast na bardzo miąższe nasypy, sięgające ponad $7 \mathrm{~m}$ poniżej powierzchni terenu. Strop osadów mioceńskich (w obrębie których znajduje się pokład węgla brunatnego) nawiercono na głębokości od 6 do ponad 15 m p.p.t. (Gontaszewska, 2015).

Głębszą budowę geologiczną wzmiankowanego obszaru można rozpoznać korzystając z map górniczych w skali 1:1000. Pomimo, że na mapach podano dane dotyczące wyłącznie zalegania pokładu węgla, pozwala to na wykreślenie na ich podstawie przekrojów geologicznych, ukazujących przebieg struktur glacitektonicznych (ryc. 6).

Pokład węgla znajduje się w obrębie zdeformowanych osadów mioceńskich, zatem znając jego położenie można odtworzyć przebieg struktur glacitektonicz- 
nych oraz typ deformacji. Informacje o jego położeniu sięgają, w opisywanym przypadku, głębokości około $70 \mathrm{~m}$ (rzędna ok. $100 \mathrm{~m}$ n.p.m.). Złoże tworzy antyklinę (tzw. siodło) o szerokości kilkudziesięciu metrów. Północne skrzydło antykliny zapada pod dużym kątem, niekiedy nawet jest pionowe, natomiast skrzydło południowe zapada pod kątem około 30-40 stopni.

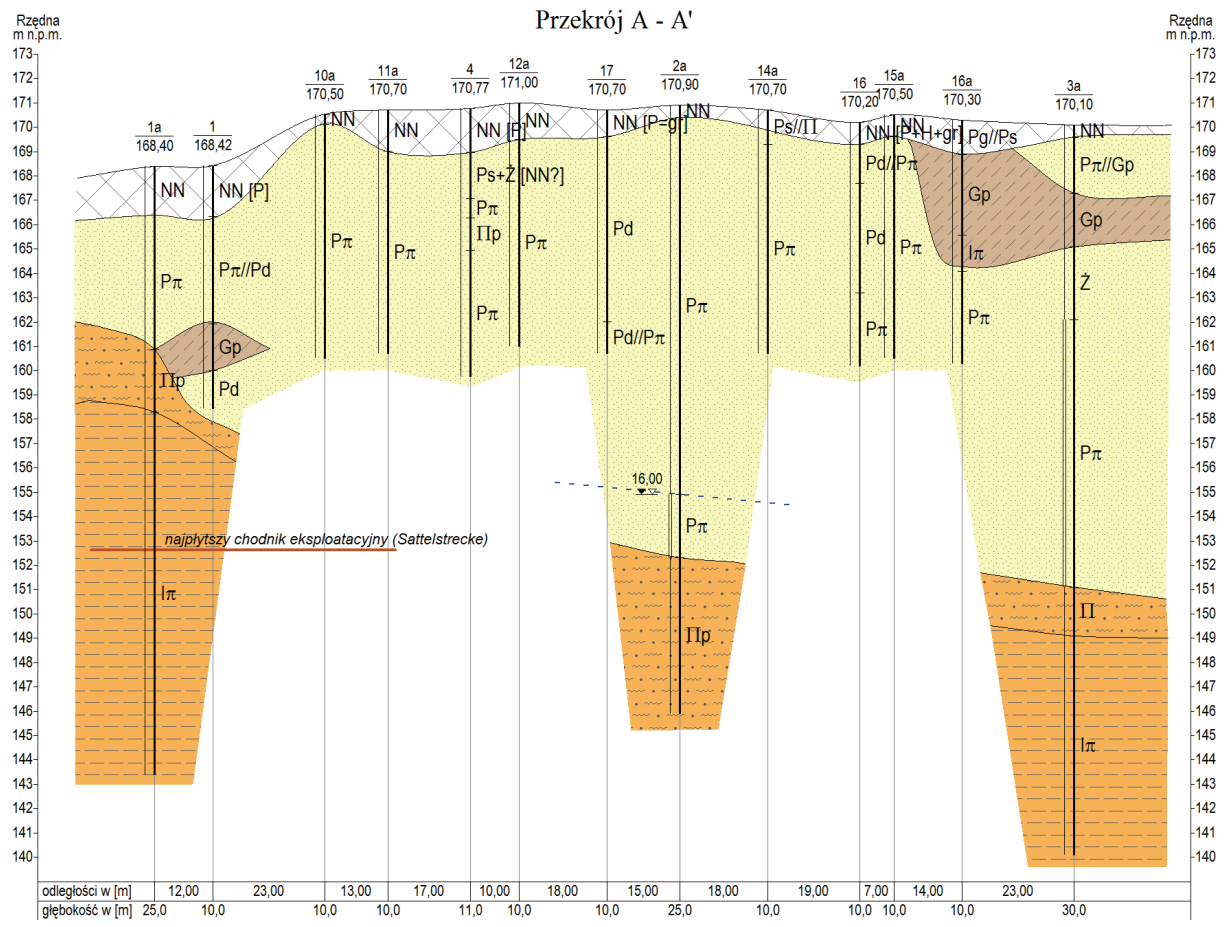

Ryc. 5. Przekrój SW-NE okolic ul. Godlewskiego w Zielonej Górze, okolice dawnego szybu „Friedrich Ost I”, objaśnienia:

$\mathrm{NN}$ - nasyp, $\mathrm{P} \pi$ - piasek pylasty, Pd - piasek drobny, Ps - piasek średni, Ż - żwir, $\mathrm{Gp}$ - glina piaszczysta, I $\pi$ - ił pylasty, Пp - pył piaszczysty (Gontaszewska, 2015)

Fig. 5. SW-NE cross-section of Godlewskiego St. in Zielona Góra, near former shaft "Friedrich Ost I", explanations:

$\mathrm{NN}$ - artificial sediment, P $\pi$ - silty sand, Pd - fine sand; Ps - medium sand, $\dot{Z}$ - gravel,

$\mathrm{Gp}-$ sandy clay (glacial), I $\pi$ - silty clay (Miocene), Пp - sandy silt (Miocene)

(Gontaszewska, 2015)

Ponadto stwierdzono obecność drugorzędnych zafałdowań w obrębie antykliny, tworzących obniżenie w części szczytowej antykliny. Obniżenie niekiedy było tak znaczne, że jego spąg znajdował się poniżej zasięgu możliwej eksploatacji (ryc. 6,7$)$. 
m n.p.m
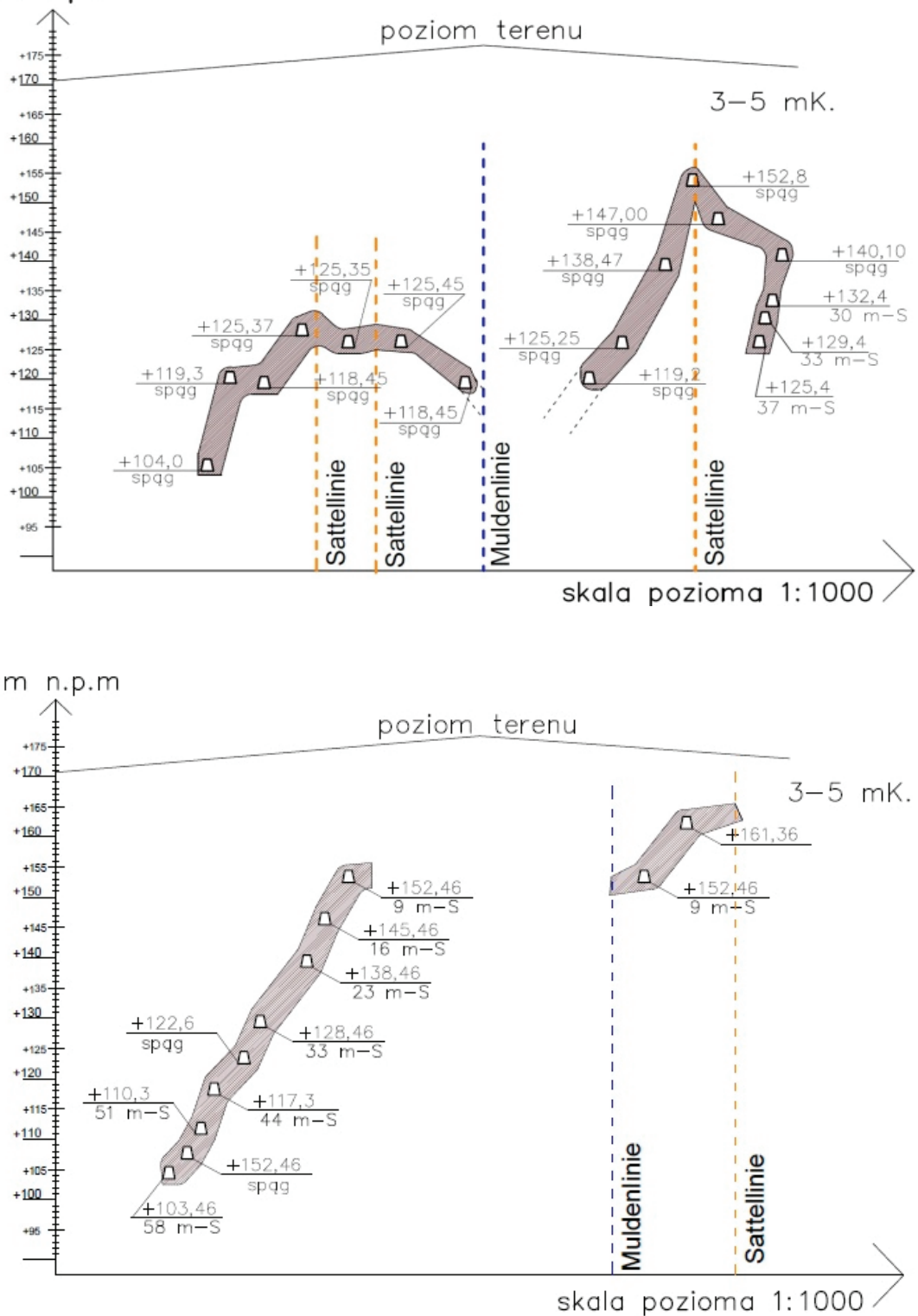

Ryc. 6. Przekroje prostopadłe do biegu antykliny eksploatowanej szybem Friedrich Ost I w Zielonej Górze. Objaśnienia: Sattellinie - linia siodła (lokalnie najwyższy punkt pokładu), Muldenlinie - linia niecki (lokalnie najniższy punkt pokładu; Szczepankowska, 2017) Fig. 6. Cross-sections of lignite anticline exploited by Friedrich Ost I shaft in Zielona Góra. Explatation: Sattellinie - saddle line (the highest point of lignite bed), Muldenlinie - basin line (the lowest point of lignite bed; Szczepankowska, 2017) 


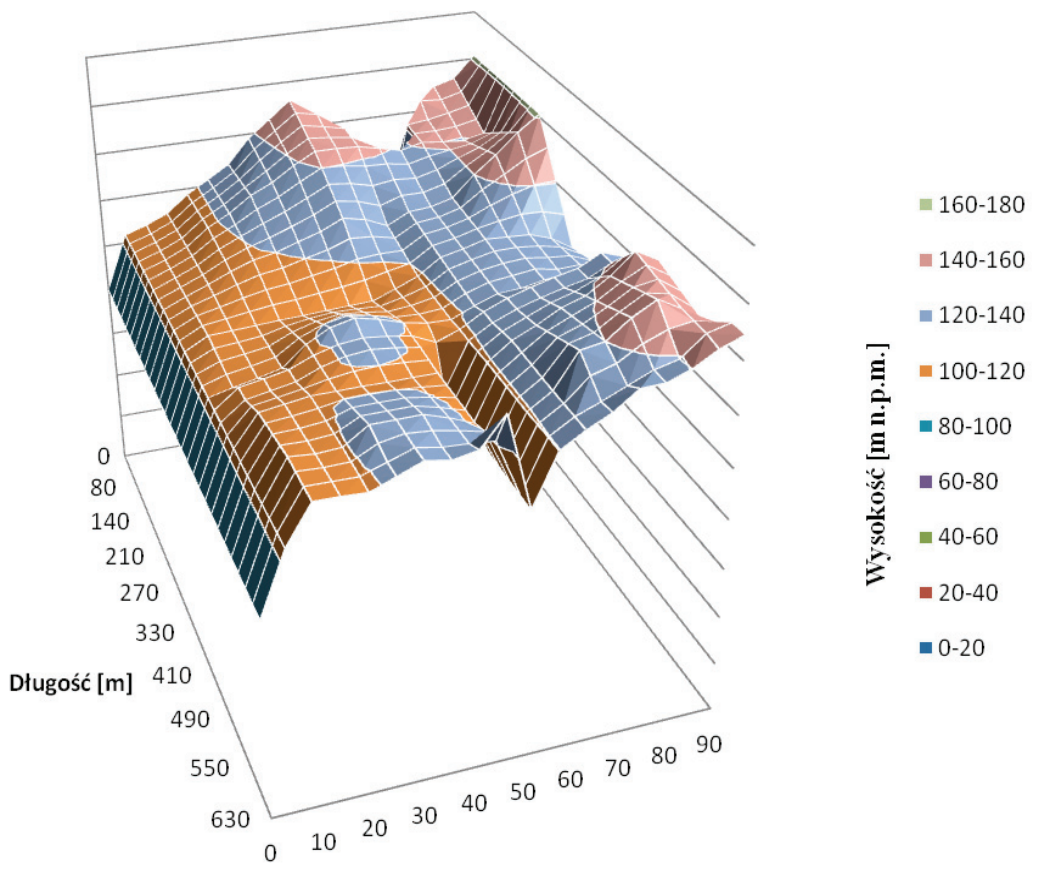

Ryc. 7. Model przestrzenny spągu pokładu węgla brunatnego eksploatowanego szybem Friedrich Ost I w Zielonej Górze (Szczepankowska, 2017) Ryc. 7. 3D-model of lignite bed exploited by Friedrich Ost I shaft in Zielona Góra (Szczepankowska, 2017)

\section{Wnioski}

Dotychczasowa interpretacja struktur glacitektonicznych, przedstawiana na mapach geologicznych oraz $\mathrm{w}$ różnych pracach dotyczących budowy geologicznej Zielonej Góry opierała się na danych pochodzących z wierceń, jak również (w zdecydowanej mniejszości) z odkrywek np. w okolicznych kopalniach iłów. Interpretacja ta była bardzo trudna, szczególnie w przypadku małej liczby głębokich odwiertów. Odwierty wykonywane wzdłuż biegu antyklin pozwalały wyinterpretować zupełnie inne struktury glacitektoniczne, np. kry (Kotowski \& Kraiński, 2002).

Analiza danych dotyczących położenia pokładu węgla brunatnego, pochodzących z map górniczych potwierdza ogólny schemat budowy geologicznej, zawarty w Szczegółowej Mapie Geologicznej Polski, arkusze Zielona Góra oraz Buchałów, gdzie pokazano łuski (zbudowane ze sfałdowanych osadów) o miąższości około $50 \mathrm{~m}$ i zasięgu poziomym około 8-10 km (Urbański, 2003). 
Analiza map górniczych pokazuje jednak, że szerokość (rozumiana jako odległość między skrzydłami) antyklin występujących na omawianym obszarze nie przekracza z reguły $100 \mathrm{~m}$. Dodatkowo antykliny te charakteryzują się także deformacjami drugiego rzędu.

Struktury glacitektoniczne widoczne na uzyskanych przekrojach są w pełni zgodne z modelem powstawania deformacji zaprezentowanym przez Kupetza (1997).

\section{Literatura}

Mapy robót górniczych. Kopalnia węgla brunatnego „Sieniawa“ w Sieniawie Lubuskiej. Archiwum Państwowe w Zielonej Górze, sygn. 2099/1317.

GONTASZEWSKA A., 2015. Dokumentacja podtoża gruntowego wraz z opinia geotechniczna działki nr 123/70 przy ulicy Godlewskiego w Zielonej Górze. Arch. A. GontaszewskiejPiekarz.

GONTASZEWSKA-PIEKARZ A., 2018. Odkrycie złóż oraz początki górnictwa węgla brunatnego w Zielonej Górze. Kwart. Hist. Nauki i Techn.: 4 (w druku).

GONTASZEWSKA-PIEKARZ A., KŁOSIŃSKI J., 2017. Geological and seismic investigation of former lignite mining area in Zielona Góra - two case studies. Journ. of Civil Engineering, Environm. and Architect., 34, 64: 311-326.

KOTOWSKI J., KRAIŃSKI A., 2002. Budowa geologiczna kry glacitektonicznej $w$ Wale Zielonogórskim (ul. Wyszyńskiego w Zielonej Górze). Zesz. Nauk. Uniw. Zielonog., Budownictwo, 129: 89-102.

KULEBA M., 2006. Wilkanowo. Wyd. Stow. Przyjaciół gminy Świdnica. Świdnica.

KUPETZ M., 1997. Geologischer Bau und Genese der Stauchendermoräne Muskauer Faltenbogen. Brandenburg. Geowissenschaft. Beiträge, 4, 2: 1-19.

URBAŃSKI K., 2003. Objaśnienia do Szczegółowej Mapy Geologicznej Polski, Arkusz Zielona Góra, Państwowy Instytut Geologiczny, Warszawa

SZCZEPANKOWSKA M., 2017. Budowa geologiczna okolic ul. Łużyckiej w Zielonej Górze. Praca magisterska, niepublikowana. Arch. Uniw. Zielonog.

\section{HISTORICAL MINE MAPS \\ AS A SOURCE OF GEOLOGICAL DATA \\ - EXAMPLE OF INTERPRETATION \\ OF GLACIOTECTONIC STRUCTURES \\ FROM THE AREA OF ZIELONA GÓRA (WEST POLAND)}

glaciotectonic structures, underground lignite mining, mine maps

A part of lignite deposits which occur in Lubusz Province relates to glacetectonically disturbed structures. In the case of Zielona Góra, it is a moraine formed during the Warta glaciation. Glacitectonic deformations caused the formation of lignite seams. The consequence of these deformations is the spatially variable and difficult to interpret geological structure. 
Lignite mines, which operated in the area of Zielona Góra until 1946, provide a lot of data on the Miocene deposits containing lignite. Mining maps indicate, among others, the layout of mine galleries and the range of old working. This allows a fairly accurate reproduction of the structure of glacitectonic structures, because the lignite layer is their most readable part.

For the fragment of Zielona Góra (near Godlewskiego Street, south-west part of the town) the analysis of available mining maps in the scale 1: 1000 was performed, comparing the results with data available from drillings and the general geological model. On the basis of mining maps containing measurements made directly in the lignite seam, simplified geological cross-sections were drawn up showing the lignite deposits. Despite the fact that the maps provide data referring to the lignite seam exclusively, they enabled drawing up geological cross-sections showing the layout of glacitectonic structures.

The lignite seam is located within the deformed Miocene sediments, so knowing its location, it is possible to reconstruct the layout of glacitectonic structures and the type of deformation. According to the information found the seam is about $70 \mathrm{~m}$ deep. The deposit forms an anticline (so-called saddle) several dozen meters wide. The northern wing of the anticline is situated at a large angle, sometimes is even vertical, while the southern wing is situated at an angle of around 30-40 degrees. Furthermore, secondary foldings, which form a depression at the apex of the anticline, were found.

The prior interpretation of glacitectonic structures, presented on geological maps and in various papers related to the geological structure of Zielona Góra, was based on data from drillings, as well as (in a substantial minority) on open pits, for example in nearby clay mines. This interpretation was very difficult, especially in the case of a small number of deep drillings. The analysis of data referring to the location of the lignite seam, obtained from mining maps confirms the general geological structure. The analysis of mining maps shows that the width (understood as the distance between the wings) of the anticlines present in the discussed area does not usually exceed $100 \mathrm{~m}$. In addition, these anticlines are also characterized by secondary deformations. Glacitectonic structures visible on the obtained cross-sections are fully consistent with the deformation model presented by Kupetz. 